Article

\title{
Four Perspectives of Sustainability Applied to the Local Food Strategy of Ghent (Belgium): Need for a Cycle of Democratic Participation?
}

\author{
Maarten Crivits ${ }^{1,2,+}$, Charlotte Prové ${ }^{1,3,+}$, Thomas Block ${ }^{2}$ and Joost Dessein ${ }^{1,2,3, *}$ \\ Received: 18 October 2015; Accepted: 30 December 2015; Published: 8 January 2016 \\ Academic Editors: Douglas H. Constance and Iain Gordon \\ 1 Social Sciences Unit, Institute for Agriculture and Fisheries Research, Burg. van Gansberghelaan 155, bus 2, \\ Merelbeke 9820, Belgium; maarten.crivits@ilvo.vlaanderen.be (M.C.); \\ charlotte.prove@ilvo.vlaanderen.be (C.P.) \\ 2 Centre for Sustainable Development, Ghent University, Poel 16, Gent 9000, Belgium; thomas.block@ugent.be \\ 3 Department of Agricultural Economics, Ghent University, Coupure Links 653, Gent 9000, Belgium \\ * Correspondence: joost.dessein@ilvo.vlaanderen.be; Tel.: +32-9-2722386 \\ + These authors contributed equally to this work.
}

\begin{abstract}
As part of cities' increasing commitment to sustainable development, local food systems are becoming a policy priority. In this article we focus on the case of a local food system in Ghent, Belgium. We adopt the notion of Hajer et al. (2015) that top-down steering of environmental issues (so-called "cockpit-ism") is insufficient, incomplete and in need of revision. Using their four perspectives on sustainable development (Hajer et al., 2015), we explore, analyze and valorize the potential of the actors, motives and logics for change within the agriculture and food system in the Ghent region. Applying these four perspectives, we have mapped the current positive developments as well as identified the weaknesses, pitfalls and opportunities of a local food strategy. The discussion section contains two important strategies for good governance of sustainable urban development: first, a governance approach to stimulate participation and representation in a complex, unequal and rapidly changing context; and second, a reflection on how local food strategies can drive global sustainability. In conclusion, we argue for the integration of a global sustainability approach within sustainable urban development.
\end{abstract}

Keywords: sustainable urban development; Hajer's sustainability perspectives; local food strategy; democratic governance; regional food system; empirical case study

\section{Introduction}

In a recent contribution to the journal Sustainability, Hajer et al. [1] have written a nuanced critique of how to redefine the Sustainable Development Goals (SDGs), a set of globally binding targets and goals adopted by the United Nations General Assembly in September 2015. Hajer and colleagues assert that "cockpit-ism", meaning the idea that top-down steering by governments alone can address global problems, will not work. Instead, multiple perspectives on sustainable development are needed to engage civil society, business and local actors as well as to respond to their needs, interests and capacities. Hajer et al. then propose four connected perspectives (hereafter referred to as "the four perspectives") that can strengthen the transformative potential of global sustainability:

(1) "Planetary boundaries", to address environmental concerns and protect public goods;

(2) "Safe and just operating space", to highlight the interconnectedness of social and environmental concerns and the issue of distribution; 
(3) "Energetic society", to grasp the willingness of a broad range of actors to take action; and

(4) "Green competition", to stimulate innovation and new practices.

All four perspectives share a common transformative potential for sustainable development. When taken separately, however, each highlights a different way of responding to "the various motives and logics of change" of the governance actors involved in establishing sustainability programs and objectives [1]. Each perspective involves different change agents and aspects that together conceptualize a more responsive model of sustainability governance. The concept of planetary boundaries delineates how human behavior impacts the ability of the Earth System (ES) to continue in a resilient and accommodating state. In this perspective, individuals have to organize their activities safely and responsibly within a set of environmental preconditions (e.g., $\mathrm{CO}_{2}$ emissions). As a concept it has persuasive strength toward national governments, but actions that respond to environmental boundaries will only be effective when the targets being set are sufficiently concrete. We will argue that seeking a positive conceptualization for how to live within the environmental planetary boundaries is equally important.

The perspective of "safe and just operating space" speaks to the social pillar of sustainability. Here, the authors call for "the construction of a social foundation to stimulate equity-based action" where resource distribution and inclusion in decision making processes will become more fair. Competition for scarce natural resources places the most vulnerable people in society at a disadvantage [2]. Ribot [2], with the idea of "substantive citizenship", urges that individuals who lack the knowledge, skills and time to "influence those who govern" should be empowered to do so. We will illustrate how a local government can start to address empowerment in relation to (1) the economic conditions of farmers and (2) inclusion in spatial development projects. The third perspective, "energetic society" focuses on a broad group of actors who already take initiative in sustainable development. Policymakers and politicians are slowly recognizing that bottom-up action can become a synergistic relationship between state and society [3]. Citizens, consumers and civil society should not only be referenced in policy objectives as a symbolic gesture, but they also have a responsibility to take action and should be called upon to do so. This perspective also relates to the challenge of bridging between public space and empowered space. Finally, the fourth perspective, "green economy", highlights the entrepreneurial dimension of sustainable development. Innovation processes in sustainable development should be self-sustaining, either on the mainstream market or via alternative market mechanisms. Governments are crucial here: they must provide support to businesses that actively strive toward sustainability, while discouraging unsustainable practices. We suggest several strategies that governments can use to encourage sustainable entrepreneurship.

While the authors [1] focus on the scale and dimension of global governance, we would like to strengthen the importance of the local level [4]. We argue that similar challenges and opportunities are applicable at the local and global levels. The bottom-up, contextual approach to social change of Hajer et al. resonates with other frameworks such as the socio-ecological perspective which has been developed in the context of health promotion $[5,6]$. That perspective explicitly identifies the interdependence of existing policies, interventions and contextual conditions to inform policymaking. Also here, it is argued that different approaches and strategies for improving health should be considered for sustainable health promotion strategies [7].

Because cockpit-ism is also a potential problem in local food strategies (LFSs), the four perspectives serve as a good entry point for developing good governance principles [8]. Cities are facing complex pressures from higher policy levels as well as from their citizens' demands for high-quality urban life [9]. In response, cities have become increasingly aware of their role in mitigating climate change and have become committed to sustainable development $[10,11]$, with local food system planning often being a major priority. Local food systems are believed to contribute to sustainable development, by addressing ecological, sociocultural, and economic issues that the dominant global agri-food system tends to externalize [12] in a more flexible way [13]. They support local autonomy of food production and encourage focus on local urban and rural concerns, such as farmland preservation 
and food access [14,15]. Local food systems re-establish spatial, social, economic and cultural connections $[13,16]$ that can result in the following contributions to sustainable development: seasonal consumption, reduction in food packaging and food transportation, generation of trust in the food system, community-building and social cohesion, education on food and sustainable development, development of local networks that stimulate ecological entrepreneurship, use and re-use of local resources, and more. [13,16,17]. This list of benefits is long, but some authors do point out that local food systems are not sustainable unto themselves [18-21]. Local is not inherently good. Without proper consideration, local food systems are at risk for overlooking the local inequalities, exclusionary mechanisms and injustices. Implicit in this critique is the notion that local sustainable food systems cannot be managed by top-down policy making alone. Instead, cities should be shifting toward a dialogue-oriented approach [11]. The assessment of a local food system for sustainable urban development should not be based on the sum of practices, but rather on the efficiency and effectiveness of governance principles in terms of their transformative potential. In other words, good governance is a precondition for sustainable development [11]. This gives rise to questions about democratic participation, inclusion and governance by a wide range of actors. In response to Hajer's [1] concerns about cockpit-ism, we propose using deliberative governance formulated by Dryzek [22] to bring all of the affected groups and representatives of relevant discourses together for the formal or informal organization of deliberative processes and collective problem solving. The intent here is to place the "local food system approach on a better political footing, one that can contribute to a more democratic local food politics" [19].

We now explore how the city of Ghent can deploy an LFS that is aligned with Ghent's climate neutral plan. We adopt Hajer and coworkers' [1] perspectives of sustainable development in our analysis and apply them to the case of the Ghent LFS. More specifically, we wish to suggest the use of these four perspectives as a heuristic framework for governance actors when developing an LFS. With "heuristics" we mean that the perspectives are intended to help structure the debate among the various stakeholders, to help them to gain insight in key issues, change logics and interdependencies while developing an LFS (As an example, see Switzer et al. [23]).

In the following section, we explain the key concept of the Ghent LFS, "Ghent en garde" as well as the data gathering and analysis process. We then explore each of the four perspectives from Hajer et al. [1] in relation to the recent developments in the LFS and in the food and agriculture system in Ghent as a whole. In the discussion, we prove the heuristic potential of Hajer and coworkers' perspectives [1] by proposing a governance approach for government officials and other responsible stakeholders. Additionally, we reflect on the scope of LFS and show how an LFS can be relevant and important even beyond the local level and suggest development of a regional food system as an additional governance principle. The overarching goal of this article is to overcome overly abstract or technical approaches to sustainability and to provide policymakers, stakeholders and citizens with a concrete and accessible approach to using LFS as one pathway to sustainable development.

\section{Methodology}

\subsection{The Context of Local Food Strategies}

For years, support of food and agriculture issues by local governments has been increasing [24]. An LFS is one way that local governments study the food system as a whole and promote sustainable food policy [25]. Institutionally, this governmental task is comparable to the role of a food policy council-also called food council or food policy advisory council/committee depending on their structure, function, or resources [26]. Food policy councils are typically government-sanctioned advisory organs that exist outside regulatory government structures; they operate on small budgets with few staff and resources [27]. Food policy councils can also take the form of civil society organizations, unsupported by local governments (e.g., Water-Duxbury Food Council in Vermont, USA; Pittsburg Food Policy Council, USA; Just Food in Ottawa, Canada). A food policy council can 
thus be defined as a board of representatives of different segments of the food system community (e.g., stakeholders or farm representatives, hunger prevention organizations, food retailers, nutritional educators, sustainable agriculture organizations, citizens, and some government officials), that shapes the food system using the political process [24-27].

In 2013, the Belgian city of Ghent launched an LFS ("Ghent en garde"). The city of approximately 250,000 citizens is currently governed by a socialist/green/center-right coalition and has committed itself to becoming a climate neutral city by the year 2050. The climate neutral plan-also called a climate strategy-serves as an overarching plan for many public and private actions. Food is one emergent focus. The policy agreement for 2013-2018 included the aim of establishing an LFS with a clear focus on local food initiatives and urban agriculture (UA) [28]. The Ghent LFS refers to a program, sanctioned by the Alderman of Environment, Climate, Energy and North/South relations. One full-time employee within the Department of Environment, Public Green and Health coordinates the LFS. It has a twofold aim: to align and support public and private action along the lines of five strategic goals (Table 1) and to set up-what they term themselves as-a food council that brings together local experts, pioneers in urban food initiatives and organizational representatives. Although Ghent has taken important steps toward realizing an LFS-as have many other European and global cities-it is struggling to find its position as a mediator, facilitator and innovator in the governance of the LFS.

Table 1. The five strategic goals of the Ghent en garde local food strategy.

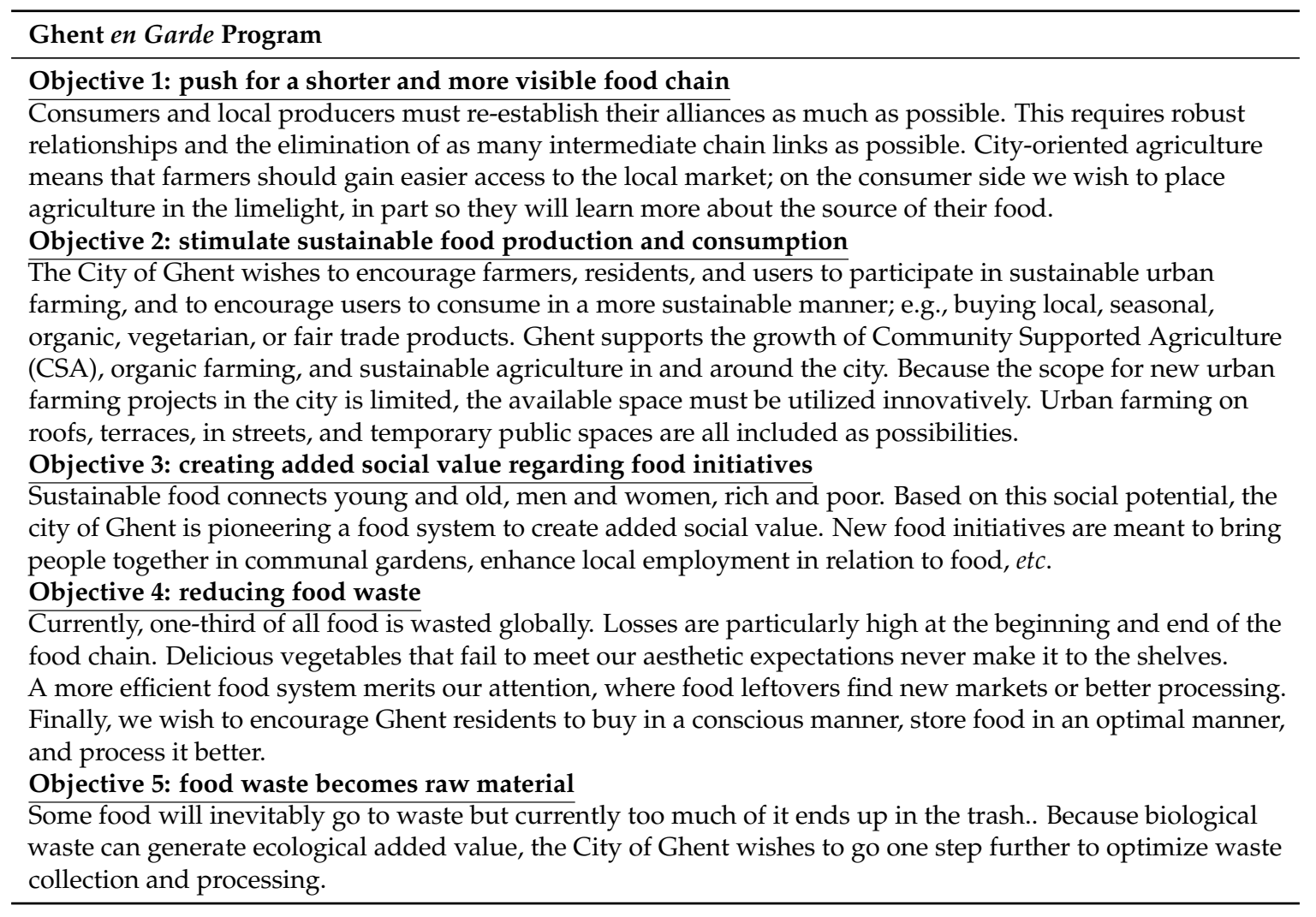

\subsection{Data Collection and Analysis}

In this article, we use a combination of qualitative research methods to understand the content and the operationalization of the LFS and the different actors involved. Starting in 2012, multiple data sources have been collected through various research projects. First, we gleaned insights from in-depth interviews with key informants in the food and agriculture system (specifically UA) in Ghent. Interviewees were selected from participant observation and a web search, followed by snowball sampling. Questions included their (1) perspective about, and involvement in, local food production 
initiatives; (2) perspective on the constitution of the network of the local food and agriculture system; (3) understanding of contextual factors that enable and constrain local food practices; and (4) predictions about the future of the local food and agriculture system in Ghent. Twenty interviews were conducted in the spring of 2013 and another 12 in the spring of 2014. Interviewees include stakeholders from the local government (administration and policymaking), LFS board members, representatives of NGOs and farming organizations, farmers, non-profit organizations and pioneers in UA. The interviews identified the strengths and weaknesses of the local food system in Ghent, the goals of the different stakeholders and perceptions of Ghent en garde. Key insights also came from participant observation as a member of the Urban Agriculture working group (a forum composed of individuals dedicated to UA in and around Ghent), as an attendee in relevant debates and workshops, or as a member/attendee at LFS board meetings. Analysis of formal (policy) and informal documents (e.g., newspapers, magazines, blogs, websites) yielded additional insights. Last, a comparative case-study was performed on UA in Philadelphia (USA) and Warsaw (Poland) supplemented by participation in focus group meetings for the 2015 launch of the "Vision for agriculture in Ghent, 2050" project (organized by the City of Ghent Department of Urban Planning). Combining the data from various time periods, sources and research goals has generated a good overview of the current developments in the food and agriculture system in Ghent. The data were consulted, (re)analyzed and discussed in light of the four abovementioned perspectives. Our analysis was validated by presenting a first draft of this paper to public officers and key stakeholders in the local food system in Ghent, then taking their feedback (including only few dissentions) into account.

The following sections address each of the four perspectives. First, the perspective is reformulated and/or expanded upon according to literature, followed by a description of recent developments and local food initiatives in Ghent. Insights in all four sections are based on in-depth interviews, participant observation and informal documentation; in Sections 3.1 and 3.4 formal policy documents were also used; and in Section 3.2, insights also come from focus group meetings. Based on our own reflections and best practices from other cases, we make suggestions about how to organize an LFS and propose potential solutions to pitfalls or barriers that render an LFS ineffective.

\section{The Four Perspectives on Sustainability}

\subsection{Planetary Boundaries}

The concept of planetary boundaries, first mentioned by Rockström et al. [29], delineates how human behavior impacts the ability of the Earth System (ES) to continue in a resilient and accommodating state. A science-based analysis named nine global priorities relating to human-induced changes to the environment: (1) climate change; (2) loss of biosphere integrity; (3) land-system change; (4) altered biogeochemical cycles (phosphorus and nitrogen); (5) stratospheric ozone depletion; (6) ocean acidification; (7) freshwater use; (8) atmospheric aerosol loading (microscopic particles in the atmosphere that affect climate and living organisms); and (9) introduction of novel entities (e.g., organic pollutants, radioactive materials, nanomaterials, and micro-plastics). A recent update by Steffen et al. [30], published in Nature, specifies that four out of the nine boundaries are currently being crossed, namely climate change, loss of biosphere integrity, land-system change, and altered biogeochemical cycles. The other five priorities are currently within the boundary. Concrete, measurable targets are crucial in the effort to maintain the Earth's carrying capacity, but environmental concerns are often vaguely worded and/or lack reference to clear goals or specific time frames [1]. We argue that local policy goals regarding environmental concerns can learn from such global environmental efforts.

Ghent belongs to a network of cities committed to becoming "climate neutral" by 2050. The current policy objective is to reduce carbon dioxide $\left(\mathrm{CO}_{2}\right)$ emissions to $20 \%$ under the 2007 levels by 2020 [31]. To this end, $€ 105$ million has been allocated for direct reduction of $\mathrm{CO}_{2}$ emissions in Ghent. More than $90 \%$ of this is earmarked for structural improvements: housing (e.g., insulation, 
energy-efficiency, renewable energy), spatial planning projects and renewal of city infrastructure. In line with Ghent's social climate policy, about $5 \%$ of the budget is dedicated to combatting energy poverty. The last portion-about $€ 1.1$ million-is dedicated to social innovation projects such as sustainability campaigns, a crowdfunding platform, and subsidies for local projects on climate change. Despite the social dimension in Ghent's climate governance, its central policy question is framed in terms of drastic $\mathrm{CO}_{2}$ reduction [31] (p. 8). Individualized and mainly technical solutions to sustainability are proposed. While in the climate strategy, the 22 most polluting companies in Ghent are excluded in the $\mathrm{CO}_{2}$ calculations due to the EU emissions trading system, the focus is on initiatives such as insulating houses, infrastructure refurbishment, energy subsidies, etc. However, these means to reduce $\mathrm{CO}_{2}$ do not tend to invigorate either social awareness or action [32]. Although $\mathrm{CO}_{2}$ targets are laudable, resolving climate change and promoting sustainability involves far more than $\mathrm{CO}_{2}$ reduction and public communication. Shove [33] convincingly shows that this type of environmental policy is based on an individualist account of autonomous choice, leaving less room for alternative conceptions of how social change can be attained, such as connecting sustainable practices, creating a stimulating environment, understanding social norms, etc.

An over-focus on $\mathrm{CO}_{2}$ reduction presents a risk of overlooking the potential positive or adverse effects of that climate strategy. Some related initiatives that produce intangible environmental, social and economic effects can be given too little attention or disregarded. For example, Community Supported Agriculture (CSA) initiatives cannot be fully characterized by $\mathrm{CO}_{2}$ reduction, but they do serve as a promising strategy to increase the sustainability of the food system. By contrast, reductions in $\mathrm{CO}_{2}$ by transferring business to another locality could be celebrated, whereas, in fact, on a global scale, no reduction in $\mathrm{CO}_{2}$ has been achieved at all.

However, we can see that the strong focus on $\mathrm{CO}_{2}$ in Ghent has been partly abandoned with the deployment of an LFS: the climate strategy for the city explicitly emphasizes that sustainability within the local food system cannot be reduced to $\mathrm{CO}_{2}$ emissions. The city states that "many consumer goods are not produced in the territory of Ghent" and therefore the city "opt[s] in favor of developing an LFS, considering the substantial impact of food production and consumption on the emission of greenhouse gases" [31]. This is in accordance with Davis and Caldeira's [34] notion of consumption-based accounting, accounting for the import and export of goods and services that involve $\mathrm{CO}_{2}$ emissions. Because of the technical difficulty of measuring $\mathrm{CO}_{2}$ emissions for activities related to the local food system, a distinct but parallel approach to the LFS was developed as part of the overall climate strategy. Interestingly, this has resulted in a framework of five strategic objectives for a more sustainable local food system (Table 1), in contrast to other topics of the climate strategy (mobility, energy, and housing), where a coherent framework is lacking. However, it remains unclear how the divergent approach of the LFS should be assessed in relation to the core objective of climate neutrality of the city. City officials acknowledge this difficulty and said that they are exploring different positions. Instead of discussing how the LFS affects the overall climate policy of Ghent, we instead use the four perspectives to analyze the course of the LFS as part of the climate strategy and the LFS activities themselves.

To move forward with the abovementioned issue of forging action within the planetary boundaries, we propose here (1) the formulation of concrete targets and (2) the focus on concepts that stimulate rather than discourage action. Although Ghent en garde clearly sets out a decisive and inspirational vision based on social, ecological and economic sustainability, it still lacks clear, measurable targets and a clear monitoring and evaluation system relating to planetary boundaries for these five goals. At the time of writing this article, several actions are being executed or planned: one day of eating vegetarian per week, a festival about food waste, encouraging restaurants to box up leftover food ("doggy bags"), and a "thinking group" about providing agricultural land. These LFS-related actions follow a communication-based and ad hoc logic, rather than working toward a definitive operationalization of targets defined in a deliberative and participative process (Section 4, below). The first step is to formulate relevant questions that can both serve to assess the societal impact of an LFS and simultaneously stimulate action on concrete targets. For example: 
1. How much land will be provided to organize multifunctional agriculture?

2. What types of food hubs will be developed in the city?

3. What percentage of city infrastructure will be greened from an agro-ecological perspective?

4. Who will participate in nutrition education programs and how will it be organized?

5. How much will food waste be reduced?

6. How many school meals will be prepared in schools, with how much locally sourced food?

7. How will unsustainable consumption be changed or reduced?

8. Because the city of Ghent cannot feed itself, how will the Ghent LFS work toward a more regional food system?

These examples illustrate the relevance of having concrete targets as the object of deliberation. Without a specification of the strategic goals, the deliberative process of the LFS might not be consequential, i.e., have a direct or indirect impact on collective decisions or social outcomes. After all, such influence is essential to a democratic system [35]. The best strategy for a deliberative process is not simply to collect the different perspectives of participants but also to negotiate potential targets and find engagement across discourses and explore integrative solutions [36].

In addition, we suggest that-specifically in relation to environmental policy—an LFS with a strong focus on UA offers the potential for a positive conceptualization of dealing with planetary boundaries. Whereas the reduction of $\mathrm{CO}_{2}$ frames the climate problem in terms of reducing human impact, UA as a strategy within LFSs proposes agro-ecological interventions that have the potential to increase the Earth's carrying capacity. The integration of ecological corridors [37] and other types of "green infrastructure" [38] on the fringe between nature and agriculture allows for positive actions toward changing the relationship between human-induced changes and the environment. Therefore, the concept of planetary boundaries should not only lead to an understanding about decreasing the impact on the environment but also to one of increasing the earth's carrying capacity.

\subsection{Safe and just Operating Space}

The perspective of safe and just operating space adds a social dimension to the concept of planetary boundaries. Human well-being depends on the balance between social and environmental boundaries. The logic of equity-based action should be integrated into the distribution of limited resources and reflected in the outcomes of the LFS such as social integration through UA, availability of locally-produced food, and access to green space. In order for everyone to benefit from a local food system, equal access to the playing field should thus be enabled. Walker [39] notes that equal access is not only about fair and efficient distribution of resources, but also about participation and inclusion in decision-making processes. As Hanagan [40] aptly puts it, "The reason why most alternative food institutions appeal primarily to middle class whites is not simply that other groups lack the means to participate in farmers' markets and CSA, but also that working class people and people of color have little input into the goals and practices of these institutions". From this, we come to understand inclusion as fair and equal opportunities to participate and benefit from the outcomes of an LFS.

Ghent is known for having a rather progressive image, represented by high numbers of students and middle class. At the same time, statistics reporting on poverty and migration numbers in Ghent show that both have been growing steadily during the past years. Interviewees stated that in Ghent topics of food, agriculture and UA receive increasing attention and that urban food activities (UA, debates, LFS) are have an open, accessible character. However, some also raised the objection that stakeholders and practitioners in the LFS - and thus those who define the shape and content of the local food system - and other related activities (such as UA) are mainly represented by the same group of young, educated, middle class citizens. Even though the social focus of the LFS cannot be ignored, in reality it pays only scant attention to groups or individuals who lack the power, skills or knowledge to participate. According to Ribot's [2] substantive citizenship, the excluded, vulnerable social groups must be seen and responded to. As a matter of fact, social inequality is increasing in Belgian cities. 
Ambitions should go beyond symbolic actions which do not exert real political influence. An explicit focus on diversity in the local food system should be a priority.

The social foundation of equity-based action and the role of government authorities need to be rebalanced in order to restore people's political and economic entitlements. In the following paragraphs we wish to illustrate this, starting with farmers and then citizens. It is worth noting that "social concerns" implies different things for different stakeholders: of course, equity-based action and inclusion for a farmer plays out in different areas of the food system than it does for a citizen, entrepreneur or policymaker.

Recently, an investigative journalist Pluymers revealed the need to review certain aspects in the agro-food chain [41]. Agricultural cooperatives can no longer guarantee prices that cover farmers' expenses and a process of scale enlargement and increased anonymity have created inequitable positions in the agricultural sector. Farmers cannot easily diversify their sales channels because many of their buyers demand exclusive contracts. Because the management of cooperatives is also under pressure from retailer tactics that have increasingly moved toward a buyer strategy, identifying the locus of accountability is not straightforward. In March 2015, various political actors have proposed that an adjudicator for the Flemish food chain would be assigned to ensure fair and legal relationships between supermarkets, suppliers and farmers [42], but that proposal was not approved. Equity in the food chain remains an unsolved, contested and extra-local issue. Although the food chain is becoming less democratic and more (inter)national, with speculative external forces exploiting local conditions for high-value niche markets [43], significant levers do exist at the local level to increase distributive justice [44]. This begs the question, how can a city enhance the just distribution of available resources and responsibilities?

A City of Ghent project launched in 2014 called "Vision for Agriculture in Ghent, 2050" [45] may illustrate one way forward. In this project, conventional farmers and their representatives, pioneers, entrepreneurs, academics, representatives of social and cultural institutions and public officers were consulted in focus groups and interviews for feedback regarding opportunities and constraints of the agriculture and food system in Ghent. The Ghent context is characterized by the lack of farmland and space to develop and sustain the farming sector. Conventional farmers have shown animosity toward new entrants to the sector focusing on local, organic and/or multi-functionality-but the project revealed a nearly complete lack of communication between the different parties about their grievances and constraints. These different parties attended workshops and began to dialogue. The participants started from many assumptions and prejudices, then gradually they began to realize that they were all facing the same constraints and they could even become partners in tackling them. Partisan and interest groups are often responsible for communication, wishing only to articulate their own interests. An LFS could therefore stimulate and promote communication between these parties, thus promoting common solutions for their shared constraints. We do not intend to suggest that stakeholder interaction is sufficient for the governance of complex issues. It remains yet to be seen what will eventually be the outcome of increased communication between competitive stakeholders. However, we argue that this is a very powerful strategy in initial phases of problem-definition and deliberation processes aiming to generate common decisions [36].

Beyond the economic realm, the aspect of justice in this context also applies to the field of urban development. Hajer et al. [1] state that a social foundation must first be built to stimulate equity-based action. Citizens need to have a fair say in, and equal access to, a local food system. In the Ghent case, much can be learned from a project called De Site. In 2003-2004, a large urban renewal project, Bridges to Rabot, was set up in the Rabot neighborhood of Ghent, one of the poorest areas in Flanders. Key to the whole process was that a one-acre brownfield became available for renovation. Initially, the neighborhood was supposed to be upgraded in the urban planning by attracting potential investments from abroad, but a whole range of socio-cultural organizations wanted to stimulate social cohesion and participation by the current residents. A local socio-artistic organization (Rocsa) wanted to write the "story of the residents to claim the space from the existing needs and requirements within 
the district, not from potential new residents, who are likely to be middle class groups" [46]. Interestingly, when external facilitators in the neighborhood asked what residents were missing, an overwhelming majority indicated the lack of a garden or green area. This resulted in a plan to make $150,4 \mathrm{~m}^{2}$ container gardens. Construction started in 2007, and the 150 gardens are still becoming increasingly popular. Strikingly, this project has brought together white middle-class residents, the Turkish community, newcomers, previously unknown groups, and many others. They met together, engaged for the first time in the community and instigated shared ownership of the space. New social networks created awareness of spatial development and forged increased inter-group solidarity. Sharing the produce, the public space and the infrastructure on the site all brought them together, as well as a cooperative organization of public events [47]. This project also heightened awareness among the wider population and spurred discussion about the social cohesion and poverty issues in the Rabot neighborhood. The external facilitator of this project was clearly an asset for creating diversity, substantive citizenship and empowerment.

A similar project to develop a community garden was initiated in the Brugse Poort, a neighboring district. No external consultants were involved in the creation of this project, called the "Boerse Poort". The decision-making and design processes were largely undertaken by the local government and key stakeholders in the district, in this case, white middle class men. Ghent officials put forward the requirement that this be a demographic and cultural mirror for the district. However, project stakeholders had a hard time establishing this mirror: migrant populations remained absent or refused to participate. These seemingly similar projects had a different approach to democratic participation in the initial phase. In De Site, a local and independent organization was given responsibility for the project. That organization had the capacity, resources and local knowledge to involve the different social groups and migrant populations at the beginning and give them a voice in the future development of their neighborhood. In contrast, the Boerse Poort project was owned by a few individuals who had already shaped the project to the needs of a specific group. Residents of the target groups remained absent, perhaps because they had no interest in developing community gardens or perhaps they felt excluded from the design process. In the realization of the project, the plots for minority groups were then assigned to people on the waiting list, regardless of their background.

The role of the local government is not to step away from all involvement, but it should be aware that its role is to know how, and especially when, to stimulate deliberation and participation. Decisions that project implementers might consider trivial in the initial phases have been shown to impact on the overall dynamic and societal relevance of the two projects. This is in accordance with Mendes [48] who claims that inclusive participation is particularly important at the beginning of a trajectory, which is characterized by problem identification and solution crafting. Additionally, governance processes should account for the dynamic character of an LFS, thus resulting in changes to goals and actors. The participatory processes must include mechanisms to ensure that actors' positions and shifting goals are represented throughout the process. Community groups in sustainable development tend to become more homogenous over time [49], reducing the bridging capacity these projects have. This is a particularly important issue to address, given that participants with less time, knowledge and the least resources are most likely to disengage first [2]. We therefore argue that setting up participatory projects requires time, resources and courage and cannot be merely standardized or replicated [50]; inducing participation and guaranteeing diversity can never be achieved in the evenings alone or on the margins of a project. Instead, it should be considered as a distinct governmental task or be assigned to an independent organizer. Local government can actively support the creation of a safe and just operating space: it can act as an arbitrator in projects and initiatives that aim to create a fair playing field and equitable distribution of resources and it can stimulate deliberative involvement and co-creation in the governance process of an LFS in which customization is required. And fortunately, a government is not alone. 


\subsection{Energetic Society}

Citizens' initiatives, social movements, knowledge institutes and companies are taking the lead in urban initiatives, creating an ever-increasing epistemic challenge for politics and governmental administrations. Bulkeley and Castan-Broto [10] argue that a blurring of public and private authority is occurring. One example is urban sustainability experiments that create new urban political spaces within the city [51]. Hajer's concept of the energetic society [52] shows how change agents all over the world have taken initiatives for sustainable development. Ostrom's idea of "polycentric governance" [53] steps away from the hierarchical system to a system undertaken from multiple centers linked only within a structure of mediation. The actors involved are free to experiment with different cooperation strategies and learn collectively. These actors can be families, individuals and other small groups of people, as well as larger organizations such as businesses, local, regional and national authorities. In other words, although we understand that local governments are increasingly driven toward expenditure control, the maxim "do it yourself" cannot be equated to the maxim "do it alone".

The city of Ghent is characterized by a wealth of efforts from a very diverse group of local actors (e.g., autonomous citizens, civil society initiatives, innovative farmers and companies, network-based groups and non-profit organizations (NPOs)). It is unclear how these new relationships between citizens, businesses, and public authorities will progress in the future, and whether the different concerns that emerge will be dealt with in a careful and proper manner, as society transitions from a welfare state to a participation society [51]. It surely cannot be the intention that public authorities, under pressure from expenditure cuts, shift numerous (generally social) responsibilities onto citizens [54] or that "big society" serves to aggravate inequality. Ghent has supported the growth of CSA initiatives, organic farming and multifunctional agriculture in and around the city, but mostly only by providing communicative and moral support. Two cases illustrate how focusing on "energetic society" can establish a more equitable and inclusive role.

The first case is a citizen initiative relating to one of the four green development areas in Ghent, the Vinderhoutse bossen (Forests of Vinderhoute). The city has acquired four acres of land with agricultural land, nature and a city-operated petting farm. A citizen initiative is now envisioning a multifunctional agro-ecological space where (city owned or public-private) CSA initiatives combine agro-tourism and ecological food production, with a potential spin-off to integrate urban farming techniques within the educative setting of the petting farm. An old farm near the city-owned acreage is for sale. The citizen group is searching for the means to acquire this estate as a public or public-private good with the aim of using it as a communal resource. An LFS could prioritize such unique possibilities for a multifunctional urban farming area and look for approaches, tools and processes to organize and envision the development of such a space. The combination of city-owned land and an actively engaged group of local citizens creates an opportunity to link the otherwise rather segregated and mono-functional zoned areas, and to stimulate further linkages between a broader set of stakeholders. Unfortunately, the local and regional planning agencies have not yet developed institutional procedures or the necessary planning instruments to combine local visioning with alternative, multifunctional modes of spatial planning. The process is still ongoing; the city's role could be decisive in the creation of the first agro-ecological and multifunctional (recreation, agriculture, nature, education) zone in Flanders.

The second case is about a missed opportunity in which the city could have facilitated the energetic society by searching for new farmers and thus acquiring land for self-organizing new local food systems (e.g., CSA) as well as for farmers who could potentially target food sales to city dwellers. In Flanders, many new farmers are searching for land to buy or lease. While the city of Ghent was at first unsure as to whether they could allocate land for any type of UA projects, an article published in the specialized press for agricultural news (Vlaams infocentrum land- en tuinbouw, VILT) revealed that the Ghent Public Centre for Social Welfare (OCMW) - which comes under the direct authority of the city - sold 250 acres of the 2900 acres it owned at the beginning of this legislature. The article stated 
that in "the past two years, seven farms and 53 acres of farmland, 20 residential houses, three acres of building land and 17 acres of forest and woodland have been sold for a total of 14.5 million euros" [55]. This observation is in sharp contrast with the scheduled budget of $€ 300,000$ over six years for the deployment of an LFS. It raises questions about how seriously the deployment of such a strategy to increase local and sustainable food systems is taken.

Of course, the government cannot be held accountable for the success of an energetic society. The challenge of reconnecting top-down with bottom-up is part of the larger political challenge of re-thinking the relationship between the state and civil society. Within the LFS, Ghent has the potential to develop a social perspective on democracy. However, an energetic society also requires the citizens to shift their perspective. Engaged citizens tend to approach policymakers individually to discuss personal projects and seeking to gain specific support for them. Interviews revealed how this mechanism of "playing favorites" still prevails in spite of calls for participatory governance. Even when governments do organize participatory events, citizens often use these instances as a means to protect personal interests or complain about policy dynamics. This perpetuates a context where the most knowledgeable, empowered and organized citizens benefit from governmental support and any opportunities that open up through the LFS. An energetic society is thus a two-way street: political agents will need to go beyond electoral concerns and consensus-based politics, and citizens will need to adopt a stance that goes beyond complaining and personality-based voting. Governance approaches are needed that sustain the energetic society by grasping and channeling grassroots efforts to effectively meet the goals of an LFS. Three examples provide inspiration.

To ensure that public land is devoted to public needs, a land bank could be established. In this way, a specific acreage of public land can be leased or sold to individuals for sustainable food production activities. For example, in Philadelphia, PA (USA) a broad group of public and private actors have been developing a land bank that came into effect in January 2015. While this has been set up because of specific problems relating to vacant land and poverty, the mechanism behind it and its intentions are a source of inspiration. From now on, public land brought into the land bank can be transferred to individuals who intend to revitalize neighborhoods or communities, including development of community gardens. On the one hand, this increases transparency in the governance process for public land and creates opportunities for new actors, while, on the other hand, it expands the group of stakeholders involved in urban initiatives (energetic society [52]).

Local food councils can also bridge between citizens and government, when they explicitly invest in public involvement and clear assignation of responsibilities [56]. The Food Policy Advisory Council in Philadelphia (FPAC) shows how this process could be developed and steered. The FPAC is represented by members appointed by the mayor, but it is strongly driven by the participation of individual citizens. The subcommittees and focus of the FPAC have been defined through debate, with the focus of the subcommittees shifting depending on the needs and dynamics at the time. The meetings are alternately held in government buildings and in public spaces (outside office hours), to stimulate the inclusion of stakeholders from outside the policy realm. The FPAC employees stimulate and promote action within Philadelphia's food and agriculture system and regularly formulate policy advice. But the voices and efforts of citizens, representatives of NGOs and institutions, and local experts are also significantly represented. It is not argued that the Ghent en garde program is exclusive to individuals outside the policy, institutional and organizational realm. We merely point out here that openness and encouraging individuals to bring their concerns and needs into the debate within the FPAC is a valuable starting point for creating an energetic society, while also contributing to the establishment of a safe and just operating space.

The third strategy to meaningfully connect the public sphere with governance space could be participatory budgeting, already applied in many cities around the world. This process of democratic deliberation and decision-making empowers citizens or neighborhoods to allocate part of a municipal or public budget. This engages the citizenry in public spending on issues of food and public open space. However, it is important to note that this will only work on condition that the participatory 
budgets represent more than a symbolic action and are not a hidden means of scouting for political campaigns [54]. Here, another reference to the danger of benefitting the most knowledgeable, informed and empowered citizens is in place [2]. Taken together, and parallel to the conclusion for the second perspective, Similar to creating a just operating space, governance approaches that feed an energetic society will require time, resources and courage, and will have to go beyond only communicating about bottom-up initiatives or the LFS in a generic way.

\subsection{Green Competition}

Processes of innovation have always found their way to the market and challenges of sustainability can be addressed in large part by developing business models. We approach the concept of green economy in a critical but constructive manner. Maintaining a link with the other dimensions of sustainability is a serious challenge and cannot be attained by merely shifting rhetoric and corporate communication. Corporate Social Responsibility (CSR) and business strategies oriented to sustainable development have become increasingly important. As the World Business Council for Sustainable Development (WBCSD) states in its new agenda for business: "Rather than follow change, business must lead this transformation by doing what business does best: cost-effectively creating solutions that people need and want. The difference is that the new solutions will be based on a global and local market place with true values and costs, the truth being established by the limits of the planet and what it takes to live well within them" [57]. First, radically new ways of delivering goods, services and well-being will require experimentation among business, policymakers and consumers. That will provide an enabling environment in which new business strategies can be developed [58-60]. These businesses can begin to account for all additional costs, such as environmental and human health costs, associated with food production that are usually not internalized in price setting [61,62]. Degrowth thinkers go even further and advocate for a full ensemble of environmental and redistributive policies, including policies for a basic income, reduction of working hours, environmental and consumption taxes and controls on advertising [63]. They argue that pricing and market mechanisms alone are unlikely to secure smooth adaptation to a society that lives better with less and that alternatives such as governing of the commons or exchange of goods and services should be explored [64,65]. Hajer et al. [1] in turn rightly indicate that governments have a clear role in (1) stimulating new business practices that actively implement sustainability as a core strategy and (2) dis-incentivizing unsustainable systems and practices. Second, fair competition is particularly important for creating economic sustainability. To exploit all possible innovations toward sustainability, every type of businesses must be able to access resources and potential market share.

The public procurement policies of Ghent in which the LFS is an active stimulator regarding public procurement of food, can illustrate both of the above points. A bottom-up campaign in Ghent called the Campaign for Local, Ecological and Fair School Lunches (LEF initiative) strives for farm-to-school programs. It has received a positive evaluation from the Alderman for Education as well as Ghent's Services and Logistics Unit. Considerable effort has already been made to integrate ecological and social sustainability criteria within the city contract for school meals, the challenge remains in finding a solution to include more business practices in a fair and sustainable manner $[60,66]$. Currently, all school meals are provided by a large national company specializing in delivering pre-prepared meals all over Belgium. Novel business practices could be given a chance in two ways: by changing procurement procedures and fostering food hubs. The procurement procedure called "lotting", a well-established and legal procurement practice, creates opportunities for smaller providers to enter the market by breaking a current contract into smaller lots. A contract to provide 450 school meals per day (=approximately one lot) offers a more realistic market segment for a small- or medium-sized enterprise (SME) specializing in sustainable school meals than the current contract of $4500 /$ meals a day. Larger companies can still bid for one or even all of the lots, but an element of fair competition has been added, thus leveling the playing field to support innovation. This shows how a city has a lever to enhance fair competition and support green niches. 
Justice in food distribution can also be created via an LFS by reconnecting food producers and consumers and using more sustainable forms of logistics [67]. The organizational model of the "food hub" focuses on adding environmental and social criteria associated with sustainable food systems and market management procedures. Although the concept of a food hub is dynamic and evolving [68], we know that it can take several forms, both physical and virtual. These can be in the city (e.g., a food hall) or in the peri-urban region (e.g., multifunctional farm or food innovation center). In Ghent, existing food hubs take the form of 18 Food Teams (organization of direct farm sales among a group of consumers and the recently introduced Fermet business (an online farmers market). Both alternative food distribution systems feature online food ordering with delivery or pick-up of the farm products from a specific location. Both initiatives have been specifically set up to support local farmers by guaranteeing a fair price. Although these types of initiatives originated from a societal concern, they are now embedded within routine consumer behavior and have a clear growth potential [69]. Even though these alternative food networks can operate successfully outside the sphere of the local government, the apparent interest and demand for such initiatives should be an incentive for local governments to support these types of practices (e.g., by providing space to organize food deliveries) and-going one step further-to initiate more structurally integrated and physically visible food hubs. These places can become more than mere consumption junctions [70], and can initiate socio-cultural processes relating to sustainable food consumption and UA. Cities such as Drumshanbo (Ireland) and Parma (Italy) actively integrate new food hubs into the city's infrastructure, allowing local economic actors to attain and secure profitable channels of sale. We acknowledge that the development of a food hub as a safe and just operating space entails a series of interventions such as (1) actively recruiting new potential producers; (2) investing in city infrastructure; (3) consistent engagement of citizens and other stakeholders; and (4) mediating a price setting that achieves a balance between a fair price for the producer and an affordable price for all local residents. Robust evidence-although confined to the global South, with a large farmer population-suggests that higher food prices reduce poverty and inequality in the long run (one to five years), because over time they also generate wage impacts and thus income redistribution [71,72]. By considering a food hub as a public space, as well as a means of invigorating consumer-producer interactions based on fair prices, a city can become both a facilitator and an arbitrator to enhance economic activity within a just, operating space.

\section{Discussion}

\subsection{Toward More Democratic Governance of Local Food Strategies}

In this article we have adopted four interconnected perspectives on sustainability [1] in the context of developing an LFS in the city of Ghent. We have demonstrated the relevance of each perspective in the case of an LFS in Ghent by describing current developments in the agriculture and food system in Ghent, including pitfalls and constraints. We have illustrated how local governments can become a facilitator, mediator and innovator in sustainable development through LFSs.

The city of Ghent explicitly advocates its choice for a social climate policy that addresses the well-being and participation of all citizens as well as achieving environmental goals [31]. We have contended that the LFS operations can lead to a process of social innovation for sustainability. As the five goals of the Ghent en garde program (Table 1) illustrate, and as we have shown for various ongoing cases in Ghent, projects relating to food and (urban) agriculture are a stepping-stone to enhance sustainability in its various forms and from different perspectives. Hajer et al. [1] specify that one way of operationalizing a sustainability strategy, is to link social well-being to sustainable management of resources (a safe and just operating space). From this perspective, an LFS should not be a strategy on its own, but should also be an impetus for other policies and programs. Poverty reduction, health policy, education, social welfare, economic development and spatial development policies could potentially be addressed by engaging in the specific practices of local food production and consumption and the development of a greener or agro-ecological infrastructure. Although these goals can be partially 
funded by connecting existing policy budgets to the social, economic and environmental benefits of local food systems, an LFS requires a substantive budget and priority status, which is usually not the case. Ghent en garde has only been granted a budget of $€ 300,000$ over a six-year period, in stark contrast with Ghent's total climate budget of $€ 105$ million. This budget seems inadequate to meet their five stated strategic goals (Table 1). Despite the small budget, numerous actions are currently being undertaken by the department, such as providing space to UA initiatives or participating in international projects that generate money for the LFS. However, without a larger budget, existing support cannot be consolidated and organization of local food activities on a larger time frame is impossible. At the same time, more weight should be given to physical resources (e.g., providing land, space for food hubs) and non-physical resources (e.g., communication, time, participation and inclusion) for the substantiation of an LFS.

Top-down local governance of an LFS is not appropriate or sufficient, however. The LFS also needs support to create a setting that enables all relevant actors to design, participate in and practice local food projects, policies and enterprises that enhance sustainability. An LFS can thus only be truly successful when the energetic society is mobilized to work together with administrators to form governmental goals and when they integrate their own views and life experience into those goals $[8,11]$. One must keep in mind here that the design of a setting never neutrally represents the public and the issue; it always constructs and transforms them, inevitably implying inclusion and exclusion. A "good" setting, then, is not one which is neutral, but one "which deforms, constrains and enables in interesting ways" $[73,74]$. We agree with Farrell and Shalizi [75] that democracy is the best way to solve complex problems, and that aiming for democratic improvements "is a commitment to making power relations more equal". This is also an important insight for the further deployment of the Ghent LFS and its overall sustainability strategy.

We now formulate some suggestions on how to develop a coherent and effective LFS in a complex, unequal and rapidly changing context by integrating the four perspectives of sustainability within a governance approach (Figure 1). This approach can be employed by government agencies and local authorities in the operationalization of the strategic goals of an LFS.

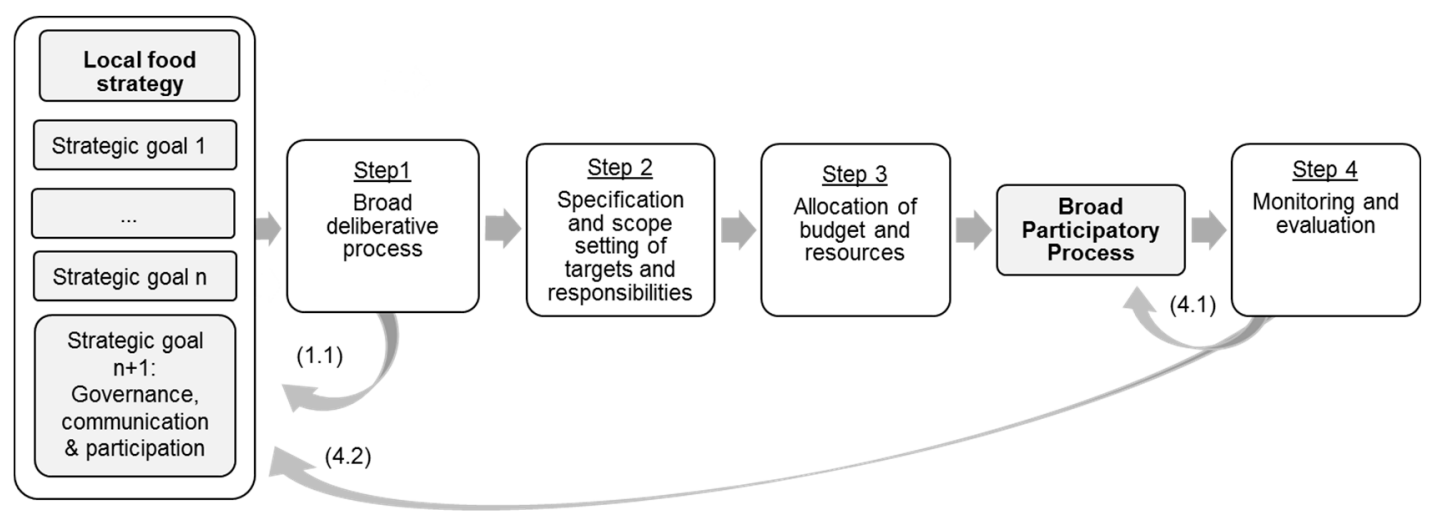

Figure 1. Governance of a Local Food Strategy (LFS): Cycle of democratic participation.

This simplified cycle of democratic participation illustrates how (LFS) governance processes could take shape in practice. As it is often argued, strategic decisions on complex issues are mostly given form and content within a governance setting in which a convergence of circumstances determines the decision-making [76], or whereby only incrementally-either through a learning process or not-decisions are reached [77-79]. Nevertheless, the figure does illustrate how local authorities could effectively make sense out of the complexity and insecurity inherent in governing an LFS. The steps can thus best be approached as a heuristic framework that enables experimentation and trial and error and that embraces insecurity, through which multiple networks can develop, grow, cooperate, evolve and take responsibility. A strong and explicit focus on substantive citizenship is imperative [2], in which actors or groups generally excluded from participatory and decision-making 
processes become represented and responded to. Well aware of the tension between ideal scenarios of democratic participation and pragmatic solutions that start from a specific situation, we present our suggestions in a four-step sequential logic.

(1) In a first step, the operational goals of an LFS should be openly shared in order to obtain deliberative assent [22]. In other words, when a local government is setting operational goals, the goals and their development should be presented in a transparent manner to all stakeholders, followed by a discussion or negotiation of those goals as needed (Steps 1.1 and 4.2). Dryzek [22] argues that such outcomes "are legitimate to the extent they receive reflective assent through participation in authentic deliberation by all those subject to the decision in question". Deliberative processes thus enable the creation of a fair and just operating space in the sense that operational goals require the inclusion of a broad set of societal actors. We have shown that by organizing a deliberative process where different and traditionally opposing groups and discourses can meet, opportunities are forged for new alliances and collective problem-solving (see the communication exercise between different types of farmers in Section 2.2 above). Ghent en garde could play a role in creating a platform for more public and bottom-up involvement and deliberation. Governance actors can play a decisive role in the design phase of sustainable projects and initiatives. We argue that a context-driven approach is required, because each urban project or bottom-up initiative is unique. The history, physical context, policy situation and complexity of the urban food context are so specific in nature that it is difficult to assess how an urban project can contribute to a sustainability transition if it is based solely on certain standardized or uniform criteria [51]. A general reflection on this first step leads us to suggest that more or less independent working groups could form around the strategic goals. Such working groups would allow participants a greater input based on their own experience or views, which fosters identification with the strategic goals and subsequently facilitates a sense of responsibility and ownership. We argue that such an approach is likely to generate more public enthusiasm than the current search for participants within the predefined strategic goals. In light of the above, we argue for the need to set up a "governance working group" for the Ghent en garde program. In this context resources and/or staff should be made available for the following: engaging (new) members or stakeholders across the different strategic goals of the LFS; communicating the LFS to the broader public; safeguarding the democratic notion of the LFS; and communicating and elaborating core concepts within the LFS, such as "local" or "sustainable". This suggestion is formulated on the level of meta-governance, but could be concretized for instance, in the form of an additional strategic goal (Strategic goal $n+1$ in Figure 1). An outsourced, external working group could also fulfill these duties.

(2) The second step is to generate outcome targets, outcome indicators and responsibilities. The deliberative processes generate the specifics and the scope of the targets. The program for the LFS will create an openness toward the concerns of different policy departments, organizations, social groups, and other individuals. It will also pave the way for a more integrative convergence of policy goals and targets across city administrations. As stated above, the expected outcome is a ripple effect of engagement, innovation, and integration not only within the local government but also in the energetic society and businesses.

(3) In time, the relevance and significance of the LFS becomes clearer and more policy domains, NGOs, organizations, businesses, farm holdings, citizens, etc. start to relate to it. As a result more adequate budgets and resources can be allocated to operationalization of the strategic goals (Step 3). Complex issues as in the cases of the multifunctional farm and sale of farmland (Section 3.3 above) or public food procurement (Section 3.4 above), which are beyond the control of the LFS, will increasingly be recognized as potential strategies to use within the LFS. As the LFS starts to encompass many environmental, social and economic benefits, mutually reinforcing synergistic relationships between government and citizens will start to be forged [3]. Concrete ties between state and society, trust-building and creation of social capital will then foster more democratic participation as a result. Instigating reciprocity between civic and entrepreneurial participation and local sustainability policy 
can become a means to create a new constituency, partially independent from electoral representation and attached to an overarching vision of regional food system (Section 4.2 below).

(4) In Step 4, collective and careful evaluation of the strategic goals, targets, action and actors in relation to the context ensures that the assigned responsibilities and formulated targets of the LFS are representative and relevant and remain so (Step 4.1) [56]. As already mentioned above, an LFS operates in a highly contextualized and dynamic sphere. Goals, stakeholders and responsibilities are likely to change, and at a relatively fast pace. Here lies the main argument for the use of outcome indicators. If the evaluation and monitoring phase identifies a discordance between the operationalization of the LFS and what is happening on the ground or, in the event of electoral change, the cyclic process should be revisited, starting again at step one (Step 4.2).

This is in no way another version of a top-down, linear management approach with local administrators holding all of the responsibility and accountability for the LFS. Even if the LFS is sanctioned by a government, the LFS is a channel for communicating different interests, voices and languages, in which responsibilities are assigned to multiple governance sources. This is line with Beck [80] who describes the emergence of a "negotiation state that arranges stages and conversations and directs the show". Nor should this be seen as a macro-governance approach, in which the LFS is coordinated from one central point in a cooperative network of stakeholders. Instead, this resonates with Ostrom's [53] notion of polycentric governance, in which governance of sustainability occurs within a structure of mediation. As stated above, the local government could take on the role of mediator, facilitator or innovator in multiple cooperative networks that coalesce around the strategic goals.

The cycle of democratic participation (Figure 1) describes how an LFS can be most efficiently and effectively organized within a given administrative territory. In the next section we expand the scope by proposing that a regional food system can be a second, complementary governance principle that directs action in an interconnected, globalized world.

\subsection{Local Strategies within a Global Network of Sustainable Development: The Regional Food System as a Guiding Principle}

An important question and concern that has so far remained unanswered, is how a shift toward the proliferation and grounding of LFSs can be a driver for global sustainable development. In the agro-food domain, the concept of sustainability is often interpreted along the lines of ensuring global food security leading to an overarching global strategy [81]. A key issue with this prominent discourse on global sustainable development is the danger of universal application regardless of local dynamics [82] and an inadequate analysis of inequalities, such as the distribution of power, costs, profits and responsibilities [74]. In contrast, an LFS is essentially concerned with the production and consumption of local resources, often seeking to move away from the global agriculture and food market $[83,84]$. While some authors warn of defensive localism, in which localization takes protectionist proportions, the local and the global scale should not be seen as being in binary opposition [18,20,21]. Such an LFS would only get into competition-for being the "greenest" or most progressive-or ignore neighboring areas that do not dispose of enough resources or a large enough energetic society to engage equally. It would also result in an exclusive alternative food system that does not address unequal social structures. Ignoring the reality of the global market on the one hand or suggesting that cities are capable of feeding themselves are equally naïve. Hinrichs [20] argues that an LFS can install a greater receptivity for diversity on the part of producers and consumers. By applying the four perspectives, we have seen that LFSs encompass more than the mere production of food (i.e., food security). They serve as a means to create social cohesion, civic engagement, economic equity and spatial planning in a context of sustainable development. We therefore argue that an LFS should aim for a broader, more inclusive integration into regional food systems and global networks, instead of striving for local food systems alone. By operationalizing an LFS from a regional food systems perspective, the global market perspective does not disappear, but rather departs from a more social and just operating space. 
In this sense, "local" comes to be understood as a relational and networked concept, rather than a mere geographic or administrative boundary $[85,86]$.

In 1992, Di Chiro [87] had already rephrased the catch phrase "think globally act locally" to "think locally, act locally and global transformation can be negotiated and realized". In other words, in addition to the question what will be produced and consumed locally, an LFS should have the ambition to ask what should not be consumed globally, in order to promote the sustainability of local food systems around the globe. This leads to modest transformation happening at the grassroots level through progressive socio-economic, cultural and environmental changes within the global food system. Organizing from the grassroots is key here-to start from the multiple, local, historically and culturally specific contexts in which people are trying to improve their social and environmental conditions [84]. The next step is then to forge a larger movement by connecting farmers and citizens' interests around the globe. LFSs should not then entail a preoccupation with the local, but be understood as a lever of local, regional and global networks for global sustainable development.

\section{Conclusions}

Global sustainability thinking can inspire local governance levels $[88,89]$. In this paper, we have adopted Hajer and coworkers' perspectives of sustainable development and applied them to the local case of the Ghent LFS. Citizen participation in the LFS, farmers co-deciding the evolution of prices, smaller enterprises gaining access to the market, or less affluent groups gaining ownership of the neighborhood all contain some form of inequality and power struggle. The role of a government is to enable a safe and just operating space, to stimulate interaction and engagement of the energetic society and to allow a broad group of actors to experiment and co-develop an LFS. In this way, they anchor a social basis for human interaction within the nine planetary boundaries. Developing a participatory governance approach - with a focus on regional food systems-to create an LFS would allow a tangible form of public discussion to determine which food system citizens imagine.

Cities all over the world are only just starting to develop LFSs. Our analysis indicates that when a government at a local level can benefit from an energetic society, as is the case in Ghent, an LFS can be a valuable social foundation for its sustainability policy. This social strategy can provide a sound starting point to establish an empowered and effective policy, which is likely to create political legitimacy. If a city succeeds in creating a large group of active stakeholders in the development of its local food and sustainability policy, this can effectively start a process of exchange with other cities, both neighboring ones and across the globe. From this perspective, local participatory arrangements contribute more effectively to global sustainability than the currently mostly top-down approaches. Making sustainability governance responsive to the different actors and logics of change allows for a reflexive and political approach towards global sustainability neither yielding to a defensive localism nor to an all-encompassing understanding of sustainable development.

Acknowledgments: The authors wish to thank the Institute of Agriculture and Fisheries Research (ILVO) for its financial support. In addition, special thanks go to the people who gave their time for additional information, feedback or review suggestions.

Author Contributions: Maarten Crivits is responsible for initiating the article and setting out the empirical analysis. Charlotte Prové and Maarten Crivits are both responsible for conducting the analysis and writing the article. Thomas Block and Joost Dessein have provided useful literature, comments and editorial suggestions on the article.

Conflicts of Interest: The authors declare no conflict of interest.

\section{References}

1. Hajer, M.; Nilsson, M.; Raworth, K.; Bakker, P.; Berkhout, F.; de Boer, Y.; Röckstrom, J.; Ludwig, K.; Kok, M. Beyond Cockpit-ism: Four insights to enhance the transformative potential of the sustainable development goals. Sustainability 2015, 7, 1651-1660. [CrossRef] 
2. Ribot, J. Cause and response: Vulnerability and climate in the Anthropocene. J. Peasant Stud. 2014, 41, 667-705. [CrossRef]

3. Evans, P.B. Government action, social capital and development: Reviewing the evidence on synergy. World Dev. 1996, 24, 1119-1132. [CrossRef]

4. Bulkeley, H. Cities and Climate Change: Urban Sustainability and Global Environmental Governance; Routledge: London, UK, 2013.

5. Whitehead, M. A typology of actions to tackle social inequalities in health. J. Epidemiol. Community Health 2007, 61, 473-478. [CrossRef] [PubMed]

6. McLeroy, K.R.; Bibeau, D.; Steckler, A.; Glanz, K. An ecological perspective on health promotion programs. Health Educ. Q. 1988, 15, 351-377. [CrossRef] [PubMed]

7. Moore, L.; de Silva-Sanigorski, A.; Moore, S.N. A socio-ecological perspective on behavioural interventions to influence food choice in schools: Alternative, complementary or synergistic? Public Health Nutr. 2003, 16, 1000-1005. [CrossRef] [PubMed]

8. Graham, J.; Amos, B.; Plumptre, T. Principles for Good Governance in the 21st Century; Policy Brief No. 15; Institute on Governance: Ottawa, ON, Canada, 2003.

9. McCormick, K.; Anderberg, S.; Coenen, L.; Neij, L. Advancing sustainable urban transformation. J. Clean. Prod. 2013, 50,1-11. [CrossRef]

10. Bulkeley, H.; Castán Broto, V. Government by experiment? Global cities and the governing of climate change. Trans. Inst. Br. Geogr. 2013, 38, 361-375. [CrossRef]

11. Evans, B.; Joas, M.; Sundback, S.; Theobald, K. Governing Sustainable Cities, 1st ed.; Earthscan: London, UK, 2005.

12. O'Hara, S.U.; Stagl, S. Global food markets and their local alternatives: A socio-ecological economic perspective. Popul. Environ. 2001, 22, 533-554. [CrossRef]

13. Seyfang, G.; Smith, A. Grassroots innovations for sustainable development: Towards a new research and policy agenda. Environ. Polit. 2007, 16, 584-603. [CrossRef]

14. Feenstra, G.W. Local food systems and sustainable communities. Am. J. Altern. Agric. 2001, 12, 28-36. [CrossRef]

15. Bellows, A.C.; Hamm, M.W. Local autonomy and sustainable development: Testing import substitution in localizing food systems: Testing import substitution in localizing food systems. Agric. Hum. Values 2001, 18, 271-284. [CrossRef]

16. Stagl, S. Local organic food markets: Potentials and limitations for contributing to sustainable development. Empirica 2002, 29, 145-162. [CrossRef]

17. Marsden, T.; Smith, E. Ecological entrepreneurship: Sustainable development in local communities through quality food production and local branding. Geoforum 2005, 36, 440-451. [CrossRef]

18. Born, B.; Purcell, M. Avoiding the local trap: Scale and food systems in planning research. J. Plan. Educ. Res. 2006, 26, 195-207. [CrossRef]

19. Dupuis, E.M.; Goodman, D. Should we go "home" to eat? Toward a reflexive politics of localism. J. Rural Stud. 2005, 21, 359-371. [CrossRef]

20. Hinrichs, C.C. The practice and politics of food system localization. J. Rural Stud. 2003, 19, 33-45. [CrossRef]

21. Winter, M. Embeddedness, the new food economy and defensive localism. J. Rural Stud. 2003, 19, 23-32. [CrossRef]

22. Dryzek, J.S. Foundations and Frontiers of Deliberative Governance; Oxford University Press: Oxford, UK, 2010.

23. Switzer, A.; Bertolini, L.; Grin, J. Transitions of mobility systems in urban regions: A heuristic framework. J. Environ. Policy Plan. 2013, 15, 141-160. [CrossRef]

24. Schiff, R. The role of food policy councils in developing sustainable food systems. J. Hunger Environ. Nutr. 2008, 3, 206-228. [CrossRef]

25. Harper, A.; Shattuck, A.; Holt-Giménez, E.; Alkon, A.; Lambrick, F. Food Policy Councils: Lessons Learned; Institute for Food and Development Policy: Oakland, CA, USA, 2009. Available online: http://www.jhsph.edu/research/centers-and-institutes/johns-hopkins-center-for-a-livable-future/_pdf/ projects/FPN/how_to_guide/getting_started/Food\%20Policy\%20Councils\%20Lessons\%20Learned.pdf (accessed on 4 December 2015).

26. Doing Food Policy Councils Right: A Guide to Development and Action. Available online: http://www. markwinne.com/wp-content/uploads/2012/09/FPC-manual.pdf (accessed on 4 December 2015). 
27. Pothukuchi, K.; Kaufman, J. Placing the food system on the urban agenda: The role of municipal institutions in food systems planning. Agric. Hum. Values 1999, 16, 213-224. [CrossRef]

28. Municipal Policy Agreement 2013-2018; Coalition of Sp.a-Groen-OpenVLD: Ghent, Belgium, 2012. Available online: https://stad.gent/sites/default/files/page/documents/Bestuursakkoord_2013_2018.pdf (accessed on 4 December 2015).

29. Rockström, J.; Steffen, W.; Noone, K.; Persson, Å.; Chapin, F.S.; Lambin, E.F.; Lenton, T.M.; Scheffer, M.; Folke, C.; Schellnhuber, H.J.; et al. A safe operating space for humanity. Nature 2009, 461, 472-475. [CrossRef] [PubMed]

30. Steffen, W.; Richardson, K.; Rockström, J.; Cornell, S.E.; Fetzer, I.; Bennett, E.M.; Biggs, R.; Carpenter, S.R.; de Vries, W.; de Wit, C.A.; et al. Planetary boundaries: Guiding human development on a changing planet. Science 2015, 347. [CrossRef] [PubMed]

31. Urban Climate Plan 2014-2019. Available online: ttps://stad.gent/over-gent-en-het-stadsbestuur/ stadsbestuur/wat-doet-het-bestuur/uitvoering-van-het-beleid/natuur-milieu/gents-klimaatplan-2014-2019 (accessed on 6 January 2016).

32. Kenis, A.; Mathijs, E. Beyond individual behaviour change: The role of power, knowledge and strategy in tackling climate change. Environ. Educ. Res. 2012, 18, 45-65. [CrossRef]

33. Shove, E. Beyond the ABC: Climate change policy and theories of social change. Environ. Plan. A 2010, 42, 1273-1285. [CrossRef]

34. Davis, S.J.; Caldeira, K. Consumption-based accounting of $\mathrm{CO}_{2}$ emissions. Proc. Natl. Acad. Sci. USA 2010, 107, 5687-5692. [CrossRef] [PubMed]

35. Dryzek, J.S. Democratization as deliberative capacity building. Comp. Political Stud. 2009, 42, 1379-1402. [CrossRef]

36. Damay, L.; Delmotte, F. New town planning instruments: Participation or governance? The case of Brussels through the "Botanique structure plan". Plan. Perspect. 2009, 25, 171-191. [CrossRef]

37. Bohn, K.; Viljoen, A. The edible city: Envisioning the continuous productive urban landscape (CPUL). Field J. 2011, 4, 149-161.

38. Tzoulas, K.; Korpela, K.; Venn, S.; Ylipelkonen, V.; Kazmierczake, A.; Niemela, J.; James, P. Promoting ecosystem and human health in urban areas using green infrastructure: A literature review. Landsc. Urban Plan. 2007, 81, 167-178. [CrossRef]

39. Walker, G. Environmental Justice: Concepts, Evidence and Politics; Routledge: London, UK, 2012.

40. Hanagan, N. From agrarian dreams to democratic realities: A Deweyian alternative to Jeffersonian food politics. Political Res. Q. 2015, 68,34-45. [CrossRef]

41. Pluymers, G. De Prijs van Goedkoop Eten (The Price of Cheap Food); Documentary of Panorama; VRT: Brussels, Belgium, 2014. Available online: http://deredactie.be/cm/vrtnieuws/videozone/programmas/ panorama/2.35547 (accessed on 29 September 2015).

42. Bourgeois Wil Arbiter Voor Agrovoedingsketen (Minister Bourgeois Wants an Adjudicator for Agro-Food Chain). Available online: http://www.vilt.be/nl_BE/news/show/id/115719/rss/1 (accessed on 29 September 2015).

43. Sage, C. The interconnected challenges for food security from a food regimes perspective: Energy, climate and malconsumption. J. Rural Stud. 2013, 29, 71-80. [CrossRef]

44. Agyeman, J.; Evans, T. Toward just sustainability in urban communities: Building equity rights with sustainable solutions. Ann. Political Soc. Sci. 2003, 590, 35-53. [CrossRef]

45. Results Study: Agriculture and Open Space in an Urban Environment. Available online: https://stad.gent/sites/default/files/page/documents/20150324_NO_Eindrapport\%20Visie\%20op\%20 Landbouw\%20-\%20kv.pdf. (accessed on 29 September 2015).

46. ROCSA vzw; Debruyne, P.; Degelin, W.; Deceur, E. Urban Agriculture: A Middle Class Practice? In Proceedings of the Ghent Forum of the Working Group for Urban Agriculture, Ghent, Belgium, 8 March 2015.

47. Debruyne, P. Urban Agriculture: A Middle Class Practice? In Proceedings of the Ghent Forum of the Working Group for Urban Agriculture, Ghent, Belgium, 8 March 2015.

48. Mendes, W. Implementing social and environmental policies in cities: The case for food policy in Vancouver, Canada. Int. J. Urban Reg. Res. 2008, 32, 942-967. [CrossRef] 
49. Newman, L.; Dale, A. Homophily and agency: Creating effective sustainable development networks. Environ. Dev. Sustain. 2007, 9, 79-90. [CrossRef]

50. Rogge, E.; Dessein, J.; Verhoeve, A. The organisation of complexity: A set of five components to organise the social interface of rural policy making. Land Use Policy 2013, 35, 329-340. [CrossRef]

51. Devolder, S.; Block, T. Transition thinking incorporated: Toward a new discussion framework on sustainable urban projects. Sustainability 2015, 7, 3269-3289. [CrossRef]

52. Hajer, M. The energetic society. In Search of a Governance Philosophy for a Clean Economy; PBL Netherlands Environmental Assessment Agency: The Hague, The Netherlands, 2011.

53. Ostrom, E. Polycentric systems for coping with collective action and global environmental change. Glob. Environ. Chang. 2010, 20, 550-557. [CrossRef]

54. Uitermark, J.; van Beek, K. Gesmoorde participatie. De schaduwkanten van "meedoen" als staatsproject. In Brave Burgers Gezocht. De Grenzen van de Activerende Overheid; Verhoeven, I., Ham, M., Eds.; Van Gennep Uitgeverij: Amsterdam, The Netherlands, 2010; pp. 227-240.

55. OCMW Gent Verkoopt Een Deel van zijn Patrimonium (OCMW Ghent Sells a Share of its Patrimonium). Available online: http://www.vilt.be/ocmw-gent-verkoopt-een-deel-van-zijn-patrimonium (accessed on 29 September 2015).

56. Coplen, A.K.; Cuneo, M. Dissolved: Lessons learned from the Portland Multnomah Food Policy Council. J. Agric. Food Syst. Community Dev. 2015, 15, 91-107.

57. World Business Council for Sustainable Development. WBCSD Vision 2050: The New Agenda for Business; WBCSD: Geneva, Switzerland, 2010. Available online: http://www.wbcsd.org/WEB/PROJECTS/BZROLE/ VISION2050-FULLREPORT_FINAL.PDF (accessed on 29 September 2015).

58. DeLind, L.B. Place, work and civic agriculture: Common fields for cultivation. Agric. Hum. Values 2002, 19, 217-224. [CrossRef]

59. Lyson, T.A. Moving toward civic agriculture. Choices 2000, 15, 42-45.

60. Tolbert, C.M.; Lyson, T.A.; Irwin, M.D. Local capitalism, civic engagement, and social well-being. Soc. Force 1998, 77, 401-427. [CrossRef]

61. Schaltegger, S.; Burritt, R. Contemporary Environmental Accounting: Issues, Concepts and Practice, Sheffield; Greenleaf Publishing: Sheffield, UK, 2000.

62. True Cost Accounting in the Food System. Available online: http://foodtank.com/news/2015/01/ true-cost-accounting-in-the-food-system (accessed on 4 December 2015).

63. D'Alisa, G.; Demaria, F.; Kallis, G. Degrowth: A Vocabulary for a New Era; Routledge: Oxon, UK, 2015.

64. Kallis, G.; Gomez, E.; Zografos, C. To value or not to value? That is not the question. Ecol. Econ. 2013, 94, 97-105. [CrossRef]

65. Daly, H.; Farley, J. Ecological Economics: Principles and Applications, 2nd ed.; Island Press: Washington, DC, USA, 2010.

66. Allen, P.; Guthman, J. From "old school" to "farm-to-school": Neoliberalization from the ground up. Agric. Hum. Values 2006, 23, 401-415. [CrossRef]

67. Blay-Palmer, A.; Landman, K.; Knezevic, I.; Hayhurst, R. Constructing resilient, transformative communities through sustainable "food hubs". Local Environ. 2003, 18, 521-528. [CrossRef]

68. Horst, M.; Ringstrom, E.; Tyman, S.K.; Ward, M.K.; Werner, V.; Born, B. Toward a more expansive understanding of food hubs. J. Agric. Food Syst. Community Dev. 2011, 2, 209-225. [CrossRef]

69. Crivits, M.; Paredis, E. Designing an explanatory practice framework: Local food systems as a case. J. Consum. Cult. 2013, 13, 1-31. [CrossRef]

70. Oosterveer, P.; Guivant, J.S.; Spaargaren, G. Shopping for green food in globalizing supermarkets: sustainability at the consumption junction. In Sage Handbook on Environment and Society; Pretty, J., Ball, A.S., Benton, T., Guivant, J.S., Lee, D.R., Orr, D., Pfeffer, M.J., Ward, H., Eds.; Sage Publications Ltd.: London, UK, 2007; pp. 411-428.

71. Headey, D. Food Prices and Poverty Reduction in the Long Run; International Food Policy Research Institute (IFPRI): Washington, DC, USA, 2014. Available online: http://ebrary.ifpri.org/cdm/ref/collection/ p15738coll2/id/128056 (accessed on 3 December 2015).

72. Ivanic, M.; Martin, W. Short-and Long-Run Impacts of Food Price Changes on Poverty; World Bank Policy Research. 2014. Available online: http://www-wds.worldbank.org/servlet/WDSContentServer/WDSP/ IB/2014/08/20/000158349_20140820111849/Rendered/PDF/WPS7011.pdf (accessed on 3 December 2015). 
73. Gomart, E.; Hajer, M. Is that politics? For an inquiry into forms in contemporary politics. In Social Studies of Science and Technology: Looking Back Ahead; Joerges, B., Nowotny, H., Eds.; Kluwer Academic Publishers: Dordrecht, The Netherlands, 2003; pp. 33-61.

74. Lahsen, M. Transnational locals: Brazilian Experiences of the climate regime. In Earthly Politics: Local and Global in Environmental Governance (Politics, Science and the Environment); Jasanoff, S., Long Martello, M., Eds.; MIT Press: Cambridge, MA, USA, 2004; pp. 151-172.

75. Farrell, H.; Shalizi, C.R. Pursuing Cognitive Democracy. In From Voice to Influence: Understanding Citizenship in a Digital Age; Allen, D., Light, J., Eds.; The University of Chicago Press: Chicago, IL, USA, 2015; pp. $211-231$.

76. Kingdon, J.W. Agendas, Alternatives and Public Policies; Little, Brown and Company: Boston, MA, USA, 1984.

77. Mintzberg, H.; Ahlstrand, B.; Lampel, J. Strategy Safari. A Guided Tour through the Wilds of Strategic Management; Free Press: New York, NY, USA, 1998.

78. Teisman, G. Models for research into decision-making processes: On phases, streams and decision-making rounds. Public Adm. 2000, 78, 937-956. [CrossRef]

79. Block, T.; Steyvers, S.; Oosterlynck, S.; Reynaert, H.; de Rynck, F. When strategic plans fail to lead. A complexity-acknowledging perspective on decision-making in urban projects. The case of Kortrijk. Eur. Plan. Stud. 2012, 20, 981-997. [CrossRef]

80. Beck, U. The reinvention of politics: Towards a theory of reflexive modernization. In Reflexive Modernization: Politics, Tradition and Aesthetics in the Modern Social Order; Beck, U., Giddens, A., Lash, S., Eds.; Polity Press: Cambridge, UK, 1997; pp. 1-55.

81. Godfray, H.C.J.; Beddington, J.R.; Crute, I.R.; Haddad, L.; Lawrence, D.; Muir, J.F.; Pretty, J.; Robinson, S.; Thomas, S.M.; Toulmin, C. Food Security: The challenge of feeding 9 billion people. Science 2010, 327, 812-818. [CrossRef] [PubMed]

82. Wesselink, A.; Buchanan, K.S.; Georgiadou, Y.; Turnhout, E. Technical knowledge, discursive spaces and politics at the science-Policy interface. Environ. Sci. Policy 2013, 30, 1-9. [CrossRef]

83. Hines, C. Localization: A Global Manifesto; Earthscan: Oxfordshire, UK, 2000.

84. Pretty, J. The Living Land: Agriculture, Food and Community Regeneration in Rural Europe; Earthscan: London, UK, 1998.

85. Paasi, A. Borders, theory and the challenge of relational thinking. Political Geogr. 2009, 30, 61-69.

86. Horlings, L.; Battaglini, E.; Dessein, J. Introduction. In Cultural Sustainability and Regional Development: Theories and Practices of Territorialisatio; Dessein, J., Battaglini, E., Horlings, L., Eds.; Routledge: Oxfordshire, UK, 2015; pp. 1-16.

87. Di Chiro, G. Defining environmental justice: Women's voice and grassroots politics. Soc. Rev. 1992, 22, 93-130.

88. Prugh, T.; Costanza, R.; Herman, D. The Local Politics of Global Sustainability; Island Press: Washington, DC, USA, 2000.

89. Bulkeley, H.; Kern, K. Local government and the governing of climate change in Germany and the UK. Urban Stud. 2006, 43, 2237-2259. [CrossRef]

(C) 2016 by the authors; licensee MDPI, Basel, Switzerland. This article is an open access article distributed under the terms and conditions of the Creative Commons by Attribution (CC-BY) license (http://creativecommons.org/licenses/by/4.0/). 